\title{
SISTEM REKAPITULASI ABSENSI DAN PENGGAJIAN PEGAWAI HONORER PADA PUSAT TEKNOLOGI INFORMASI DAN KOMUNIKASI KEMENTERIAN PERHUBUNGAN
}

\author{
Ayu Anggraini ${ }^{1}$, Ummu Radiyah ${ }^{2}$ \\ Program Studi Teknik Informatika \\ Fakultas Teknik \\ Sekolah Tinggi Manajemen Informatika dan Komputer Nusa Mandiri \\ Aanggraini30@gmail.com
}

\begin{abstract}
Abstrak: Sistem Rekapitulasi Absensi dan Penggajian Pegawai Honorer Pada Pusat Teknologi Informasi dan Komunikasi Kementerian Perhubungan. Sistem Rekapitulasi Absensi dan Penggajian untuk Pegawai Honorer yang selama ini masih manual dengan menggunakan tarik data pdf atau xls via finger print dan di export ke dalam Microsoft Excel untuk diolah kembali sebagai data dukung dalam penggajian Pegawai Honorer. Dengan bertambahnya pegawai honorer yang ada pada Kantor Pusat Teknologi Informasi dan Komunikasi Kementerian Perhubungan, proses rekapitulasi absensi menggunakan cara manual dianggap kurang efektif dan efisien dikarenakan semakin bertambahnya jumlah pegawai yang ada di kantor tersebut semakin bertambah pula data yang harus diolah secara manual. Dengan demikian perlu adanya sistem rekapitulasi berbasis web agar mempercepat proses rekapitulasi.
\end{abstract}

Kata kunci: Sistem Rekapitulasi Absensi dan Penggajian, Honorer, Kementerian Perhubungan

\begin{abstract}
Attendance and Payroll System for Honorary Staff at the Ministry of Transportation's Information and Communication Technology Center. Presence and Payroll Recapitulation System for Honorary Employees is still manual using pdf or xls data pull via finger print and exported into Microsoft Excel to be reprocessed as supporting data in Honorary Employee payroll. The increasing number of honorary staff at the Ministry of Transportation's Information and Communication Technology Center., the process of presenting recapitulation using the manual method is considered to be less effective and efficient because the increasing number of employees in the office also increases the data that must be processed manually. Based on that, a web-based recapitulation system is needed to speed up the recapitulation process
\end{abstract}

Keywords: Attendance and Payroll System, Honorary, Ministry of Transportation

\section{PENDAhUluan}

Latar belakang masalah teknologi sistem informasi sangat berfungsi dalam memperbaiki mutu suatu institusi. Dengan memanfaatkan teknologi sistem informasi yang terstruktur akan memperoleh data yang akurat secara efisien. Satu di antaranya data yang berguna dalam suatu institusi yaitu data pegawai. Data yang dibutuhkan antara lain pegawai tersebut secara rinci mulai dari status kepegawaian, jam kedatangan ataupun absensi serta penggajian. Dokumen dalam sistem penggajian hendaknya lengkap serta transparan, supaya tidak

Ciptaan disebarluaskan di bawah Lisensi Creative Commons Atribusi 4.0 Internasional. 
terjadi kecurangan- kecurangan yang tidak diinginkan [1]. Menurut Mulyadi [2], berikut ini dokumen yang harus disertakan pada saat proses pemberian gaji yang akan di input kedalam sistem yaitu:

a) Dokumen Pendukung untuk Penggajian ini biasanya dikeluarkan oleh bidang kepegawaian berbentuk surat keputusan (SK) terkait dengan pegawai itu sendiri.

b) Rekapitulasi Absensi digunakan untuk pencatatan jam kehadiran pegawai honorer di institusi. Catatan jam kehadiran ini bisa berbentuk catatan hadir biasa ataupun berupa finger print yang akan ditarik informasinya ke dalam file komputer. Identifikasi Masalah Bedasarkan pada uraian latar belakang permasalahan di atas maka diperoleh identifikasi permasalahan yaitu "Bagaimana membuat sistem rekapitulasi absensi dan penggajian honorer untuk mempermudah Bagian Kepegawaian dan Keuangan melakukan rekapitulasi absensi dan mengurangi presentase human error dalam melakukan penghitungan gaji pegawai honorer". Tujuan Penelitian yaitu alternatif solusi untuk memudahkan proses rekapitulasi absensi dan penggajian pegawai honorer agar lebih efektif dan efisien.

\section{METODE DAN MATERI}

Untuk sistem ini menggunakan metode waterfall yaitu Metode waterfall atau metode air terjun merupakan salah satu siklus hidup klasic (Classic life cycle) dalam pengembangan perangkat lunak. Metode ini menggambarkan pendekatan yang cukup sistematis juga berurutan pada pengembangan software.

\subsection{Teknik Pengumpulan Data}

Observasi Salah satu teknik pengumpulan data yang cukup efektif untuk mempelajari suatu sistem adalah teknik observasi atau pengamatan

Wawancara Penulis memperoleh data-data serta meneliti kebenaran informasi dengan melakukan sesi tanya jawab dengan Bagian Kepegawaian dan Keuangan Pusat Teknologi Informasi dan Komunikasi Perhubungan Kemenhub untuk mendapatkan data dan informasi yang akurat.

Studi Pustaka Melakukan studi kepustakaan untuk mengumpulkan data dan informasi yang diperoleh dari artikel-artikel ilmiah, buku - buku, dan internet terkait dengan penelitian ini.

\subsection{Model Pengembangan Sistem}

Analisis kebutuhan sistem sangat diperlukan dalam mendukung kinerja suatu aplikasi. Analisa kebutuhan yang dilakukan pada perangkat lunak akan menghasilkan spesifikasi kebutuhan perangkat lunak, dalam analisa dokumen yang dibutuhkan adalah Data Absensi Pegawai.

Desain UML (Unified Modeling Language) untuk pembuatan Use Case Diagram, Activity Diagram, Sequence Diagram, Component Diagram, Deployment Diagram dan desain database dengan Entity Relationship Diagram dan Logical Record Structure.

Code generation menggunakan bahasa pemrograman PHP yang merupakan salah satu bahasa pemrograman yang berbasis objek, oleh karena itu penulis akan mendesain program berbasis objek atau Object Oriented Programming (OOP).

Testing Pada tahap ini, penulis akan meneliti kemampuan dari program dengan melakukan Black Box Testing untuk mendapatkan hasil yang diharapkan.

Support Dalam membangun aplikasi sistem informasi absensi dan penggajian ini, penulis menggunakan software yang terdiri dari Basis Data, Sublime Text, Xampp, Photoshop CS6, StarUML, Sedangkan untuk hardware yang digunakan dalam menunjang pembuatan aplikasi ini yaitu Notebook ASUS X441U dengan spesifikasi Proccesor Intel i3-6006U, VGA Nvidia GeForce 920MX, RAM 4GB, HDD 500GB , ODD DVD Sup.MTL, OS WIN10 dan Monitor 14inch.

\section{PEMBAHASAN DAN HASIL}

Proses bisnis sistem ini akan menjelaskan yaitu setiap pegawai harus melakukan absen saat masuk dan pulang kerja dengan menggunakan alat finger print yang tersedia. Alat finger print akan memproses sidik jari pegawai, apabila sidik jari tidak terbaca oleh alat finger print, maka pegawai tersebut harus mencobanya sampai

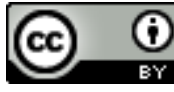

Ciptaan disebarluaskan di bawah Lisensi Creative Commons Atribusi 4.0 Internasional. 
berhasil. Setelah berhasil alat finger print akan menyimpan data hasil absensi yang tercatat sebagai jam datang maupun jam pulang.

Setelah itu petugas menerima data absensi berformat pdf dari Biro Kepegawaian, lalu kemudian file pdf tersebut di export ke dalam file excel sebelum dilakukan proses evaluasi absensi. Proses evaluasi absensi dilakukan dengan mengimport file absensi ke dalam sistem kemudian evaluasi dilakukan oleh petugas. Evaluasi absensi adalah mengevaluasi siapa saja pegawai yang mengalami keterlambatan dan pulang sebelum waktunya, lupa absen, alpa, izin, cuti, perjalanan dinas dan rapat. Setelah proses evaluasi absensi selesai dilakukan, petugas dapat melihat rekapitulasi absensi dan laporan penggajian pegawai.

Contoh:

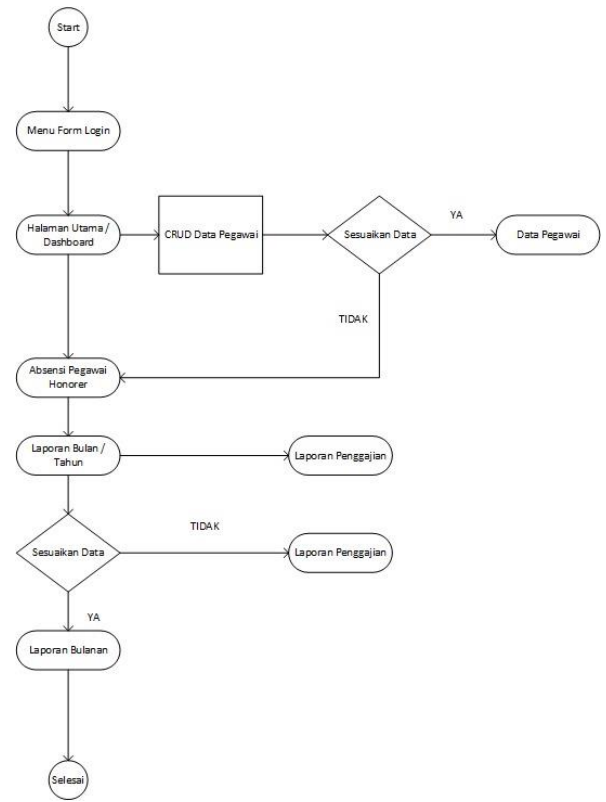

Gambar 1. Proses Alur Sistem

Mengenai Gambar 1 Proses alur sistem, dimana gambar tersebut merupakan alur dari sistem.

1. Mulai Proses awal ketika memulai pembuatan Sistem Absensi Pegawai Honorer.

2. Login Sistem Informasi Absensi Pegawai Honorer PustikomHub.

3. Dashboard Pada tahap ini terdapat tampilan utama pada halaman yang terdapat banyak menu dalam Sistem Absensi Pegawai honorer PustikomHub.

4. CRUD data Pegawai Proses selanjutnya CRUD yaitu Create, Read, Update, dan Delete yaitu penulis bisa menginput, memperbaharui, dan menghapus beberapa data pegawai seperti Nama Pegawai, NIP, Jabatan, Penempatan

5. Kesesuaian Data Pada Tahap ini data-data peserta sudah terinput dalam data pegawai.

6. Data Absen Pegawai Dalam tahap ini menampilkan nama pegawai yang absen.

7. Laporan Bulanan atau Tahunan bagian ini terdapat dua proses ialah laporan absensi bulanan dan laporan absensi tahunan.

8. Laporan Penggajian bagian ini laporan akan tersedia jika laporan bulanan telah selesai di rekapitulasi

9. Pilihan Laporan bulanan tahap ini jika Ya, maka muncul laporan absen kerja pegawai selama satu bulan

10. Laporan Tahunan Jika Tidak, maka akan muncul pilihan laporan absen kerja pegawai selama satu tahun

11. Selesai Pada bagian ini tahap dimana semua proses telah dikerjakan dengan selesai

IV. ANALISA KEBUTUHAN SOFTWARE

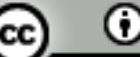

Ciptaan disebarluaskan di bawah Lisensi Creative Commons Atribusi 4.0 Internasional. 


\subsection{Tahapan Analisis}

Sistem Rekapitulasi Absensi dan Penggajian berbasis web dimana setiap pegawai honorer melakukan absensi melalui finger print yang dimiliki oleh Biro Umum Kementerian Perhubungan dan nantinya file pdf hasil rekap data absensi dikirimkan ke Pustikomhub setiap bulannya. File pdf tersebut di export ke dalam file Microsoft excel dan disesuaikan dengan template import lalu file tersebut di import ke dalam Sistem Rekapitulasi Absensi dan Penggajian dengan begitu proses rekap absensi dapat diolah di sistem dan rekapitulasi penggajian langsung terintegrasi sesuai data kehadirannya. Berikut spesifikasi kebutuhan (system requirement) dari Sistem Rekapitulasi Absensi dan Penggajian;

Halaman Admin:

1. Dapat login.

2. Dapat logout.

3. Dapat melihat dashboard monitoring kehadiran.

4. Dapat mengelola daftar hadir pegawai.

5. Dapat mengimport data pada form daftar hadir.

6. Dapat melihat data pada form daftar hadir pegawai

7. Dapat edit keterangan pada form daftar hadir.

8. Dapat melihat report absensi bulanan.

9. Dapat melihat report absensi tahunan.

10. Dapat melakukan export data ke file Microsoft excel pada form report absensi tahunan.

11. Dapat melihat rekapitulasi gaji perbulan.

12. Dapat melakukan export data ke file Microsoft excel pada form rekapitulasi gaji per tahun.

13. Dapat melakukan pengaturan jam kerja.

14. Dapat mengelola data pegawai.

15. Dapat melakukan tambah data pada form data pegawai.

16. Dapat melakukan hapus data pada form data pegawai.

17. Dapat melakukan edit data pada form data pegawai.

\subsection{Use Case Diagram}

Use Case Diagram digunakan untuk mengetahui fungsi apa saja yang ada di dalam sebuah sistem dan apa saja fungsi-fungsi sistem tersebut.

1. Use Case Diagram Halaman Admin

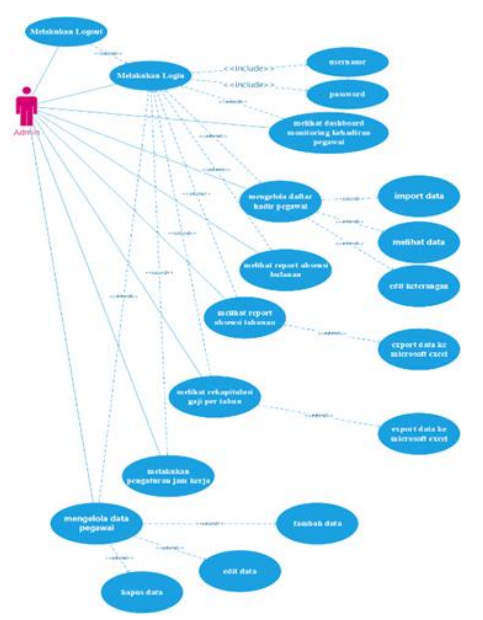

Gambar 2. Use Case Diagram Halaman Admin

Deskripsi Use Case Diagram Sistem Rekapitulasi dan Penggajian Pegawai Honorer Halaman Admin:

Tabel 1. Deskripsi Use Case Diagram Halaman Admin

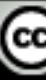

Ciptaan disebarluaskan di bawah Lisensi Creative Commons Atribusi 4.0 Internasional. 


\begin{tabular}{|c|c|}
\hline Use Case Name & Admin Melakukan Login \\
\hline Requirements & A1-A17 \\
\hline Goal & $\begin{array}{l}\text { Admin dapat mengelola Sistem Rekapitulasi Absensi dan Penggajian Pegawai Honorer } \\
\text { Pusat Teknologi Informasi dan Komunikasi Perhubungan }\end{array}$ \\
\hline Pre-Conditions & Admin melakukan login terlebih dahulu \\
\hline Post-Conditions & Admin mengelola Sistem Rekapitulasi dan Penggajian Pegawai \\
\hline Primary Actors & Admin \\
\hline $\begin{array}{c}\text { Main Flow/Basic } \\
\text { Path }\end{array}$ & $\begin{array}{l}\text { 1. Dapat melihat dashboard monitoring kehadiran pegawai. } \\
\text { 2. Dapat mengelola daftar hadir pegawai. } \\
\text { 3. Dapat melihat report absensi bulanan. } \\
\text { 4. Dapat melihat report absensi tahunan. } \\
\text { 5. Dapat melihat rekapitulasi gaji per tahun. } \\
\text { 6. Dapat melakukan pengaturan jam kerja. } \\
\text { 7. Dapat mengelola data pegawai. }\end{array}$ \\
\hline Invariant A: & \\
\hline
\end{tabular}

\subsection{Activity Diagram}

1. Activity Diagram Admin Mengelola Daftar Hadir Pegawai.

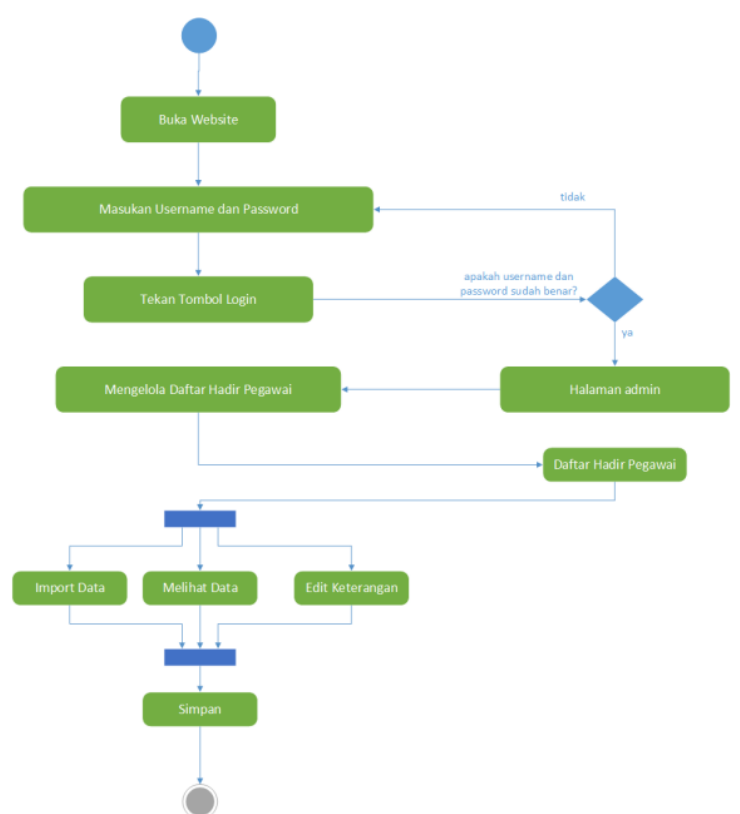

Gambar 3. Activity Diagram Admin Mengelola Daftar Hadir Pegawai

2. Activity Diagram Admin Mengelola Data Pegawai

\footnotetext{
Ciptaan disebarluaskan di bawah Lisensi Creative Commons Atribusi 4.0 Internasional.
} 


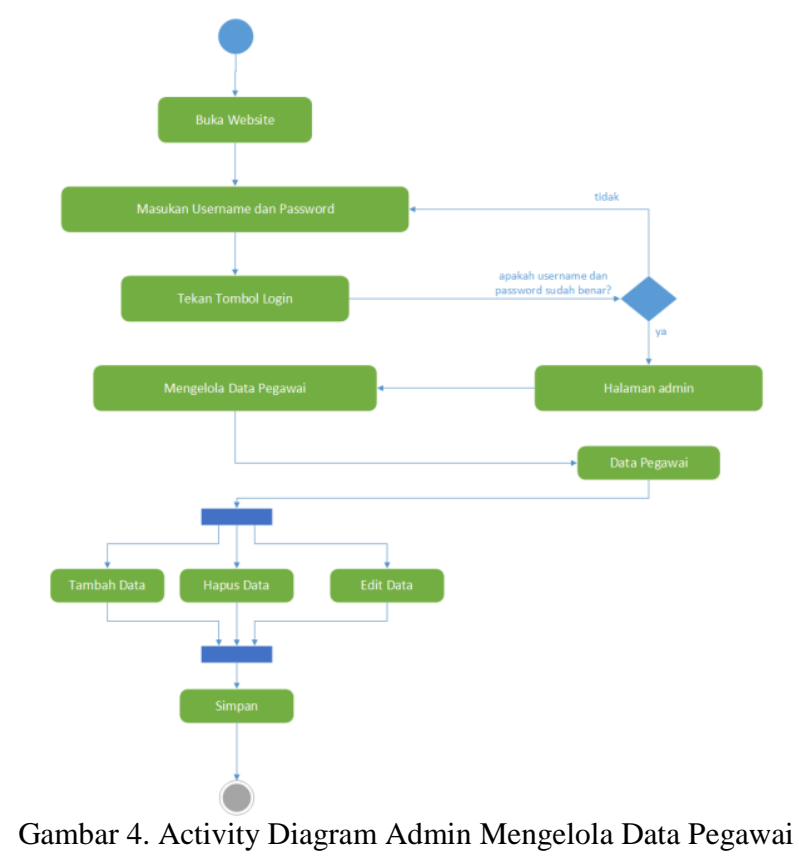

\subsection{Desain}

Database

ERD (Entity Relationship Diagram) adalah gambaran database yang digunakan dalam Sistem Rekapitulasi Absensi dan Penggajian Pustikomhub berbasis web.

\section{ERD (Entity Relationship Diagram)}

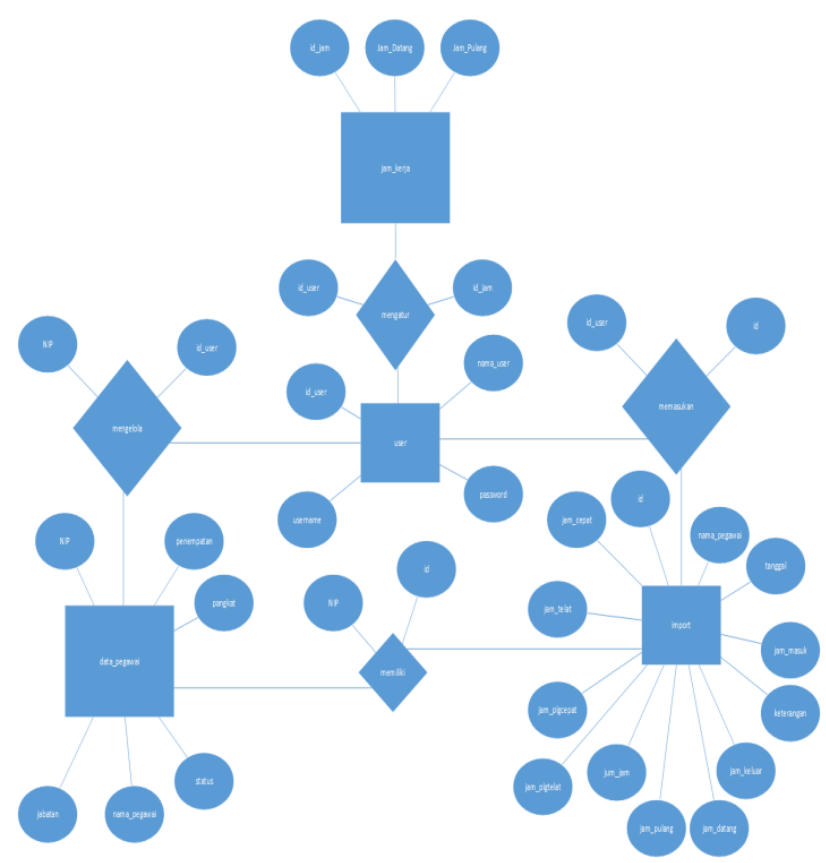

Gambar 5. ERD (Entity Relationship Diagram) 
2. LRS (Logical Record Structure)

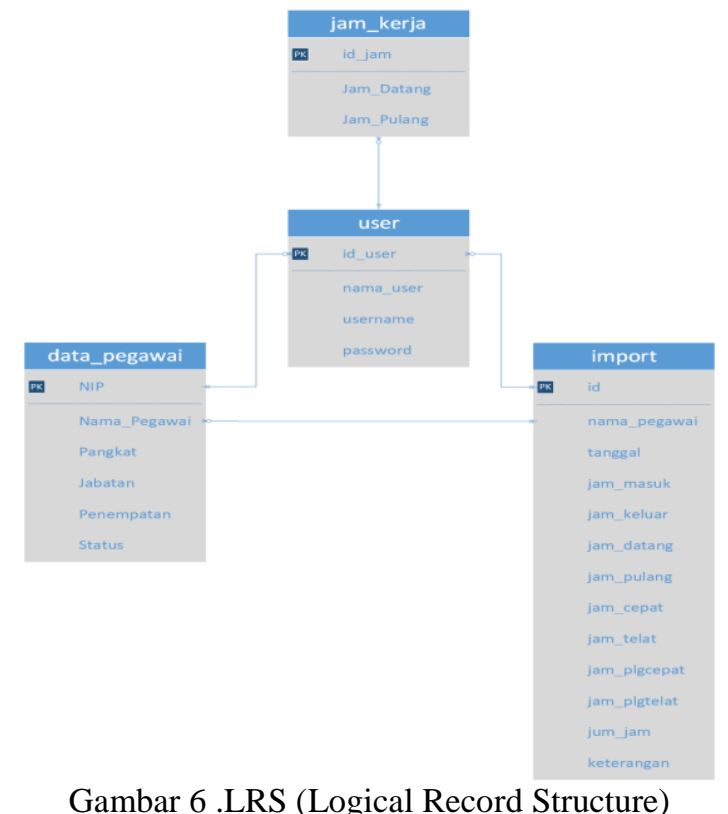

\section{Spesifikasi File}

Dengan nama database absen.sql

a. Spesifikasi File Tabel User

Nama File : Tabel User

Akronim : user

Tipe File : File Master

Akses File : Random

Panjang record : 65

Kunci field : id_user

Tabel 2. Spesifikasi File Tabel User

\begin{tabular}{|c|c|c|c|c|c|}
\hline No. & Elemen Data & Nama Field & Tipe & Size & Keterangan \\
\hline 1 & Id User & id_user & int & 5 & Primary Key \\
\hline 2 & Nama User & nama_user & varchar & 20 & \\
\hline 3 & Username & username & varchar & 20 & \\
\hline 4 & Password & password & varchar & 20 & \\
\hline
\end{tabular}

b. Spesifikasi File Tabel jam_kerja

Nama File : Tabel jam_kerja

Akronim : t_jam_kerja

Tipe File : File Master

Akses File : Random

Panjang record : 15

Kunci field : id_jam

Tabel 3. Spesifikasi File Tabel jam_kerja

\begin{tabular}{|c|c|c|c|c|c|}
\hline No. & Elemen Data & Nama Field & Tipe & Size & Keterangan \\
\hline 1 & Id Jam & id_jam & int & 15 & Primary Key \\
\hline 2 & Jam Datang & jam_datang & time & & \\
\hline 3 & Jam Pulang & jam_pulang & time & & \\
\hline
\end{tabular}


c. Spesifikasi File Tabel import

Nama File : Tabel import

Akronim : t_import

Tipe File : File Master

Akses File : Random

Panjang record : 290

Kunci field : id

Tabel 4. Spesifikasi File Tabel import

\begin{tabular}{|c|c|c|c|c|c|}
\hline No. & Elemen Data & Nama Field & Tipe & Size & Keterangan \\
\hline 1 & Id Import & id & int & 20 & Primary Key \\
\hline 2 & Nama Pegawai & nama_pegawai & varchar & 50 & \\
\hline 3 & Tanggal & tanggal & varchar & 20 & \\
\hline 4 & Jam Masuk & jam_masuk & varchar & 20 & \\
\hline 5 & Jam Keluar & jam_keluar & varchar & 20 & \\
\hline 6 & Jam Datang & jam_datang & varchar & 20 & \\
\hline 7 & Jam Pulang & jam_pulang & varchar & 20 & \\
\hline 8 & Jam Cepat & jam_cepat & varchar & 20 & \\
\hline 9 & Jam Telat & jam_tela & varchar & 20 & \\
\hline 10 & Jam Pulang Cepat & jam_plgcepat & varchar & 20 & \\
\hline 11 & Jam Pulang Telat & jam_plgtelat & varchar & 20 & \\
\hline 12 & Jumlah Jam & jum_jam & varchar & 20 & \\
\hline 13 & Keterangan & keterangan & varchar & 20 & \\
\hline
\end{tabular}

d. Spesifikasi File Tabel Data Pegawai

Nama File : Tabel data_pegawai

Akronim : t_data_pegawai

Tipe File : File Master

Akses File : Random

Panjang record : 270

Kunci field : NIP

Tabel 5. Spesifikasi File Tabel data_pegawai

\begin{tabular}{|c|c|c|c|c|c|}
\hline No. & Elemen Data & Nama Field & Tipe & Size & Keterangan \\
\hline 1 & NIP & NIP & varchar & 50 & Primary Key \\
\hline 2 & Nama Pegawai & Nama_Pegawai & varchar & 50 & \\
\hline 3 & Pangkat & Pangkat & varchar & 50 & \\
\hline 4 & Jabatan & Jabatan & varchar & 50 & \\
\end{tabular}

\subsection{Software Architecture}

\section{Deployment Diagram}

Deployment diagram terdiri dari node yang merupakan perangkat keras fisik yang digunakan untuk menyebarkan aplikasi. Tiap node pada deployment diagram mewakili satu unit komputasi sistem yang dalam banyak hal merupakan bagian dari perangkat keras. Deployment diagram dalam sistem ini menggambarkan bagaimana sistem website dapat terlihat.

Ciptaan disebarluaskan di bawah Lisensi Creative Commons Atribusi 4.0 Internasional. 


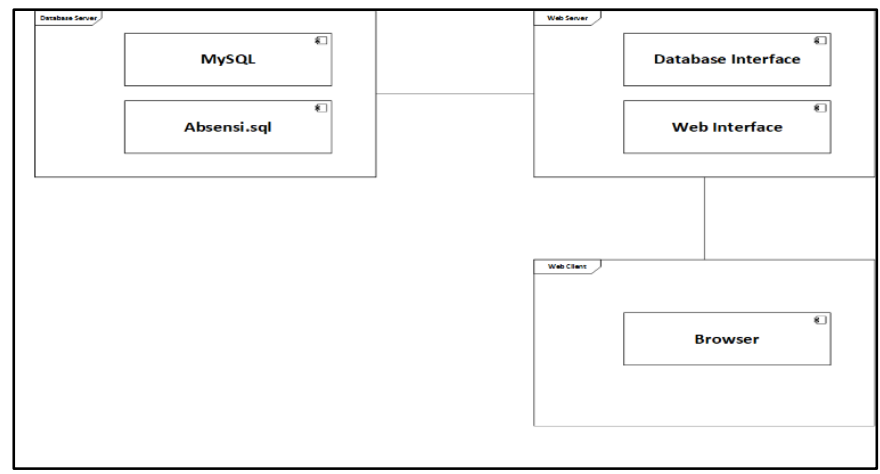

Gambar 7. Deployment Diagram Sistem Rekapitulasi Absensi dan Penggajian

\section{Component Diagram}

Component diagram menggambarkan struktur dan hubungan antar komponen piranti lunak, termasuk ketergantungan (dependency) di antaranya, komponen piranti lunak adalah modul berisi code, baik berisi source code maupun binary code, baik library maupun executable, baik yang muncul pada compile time, link time, maupun run time. Komponen dapat juga berupa interface, yaitu kumpulan layanan yang disediakan sebuah komponen untuk komponen lain.

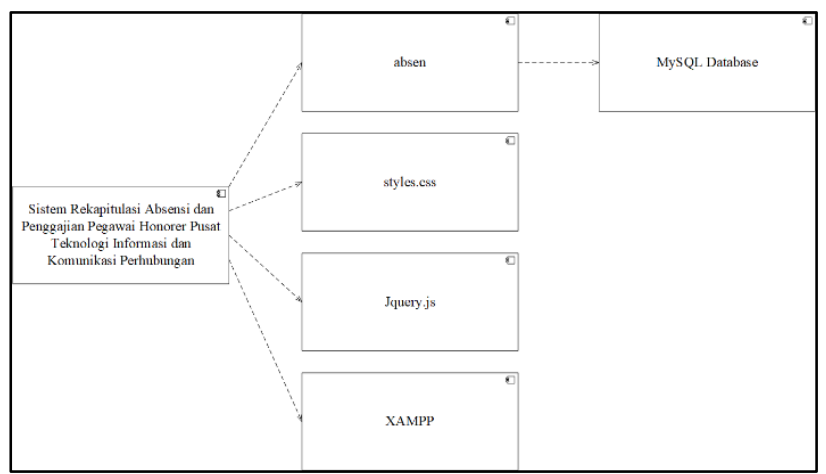

Gambar 8. Component Diagram Sistem Rekapitulasi Absensi dan Penggajian Pegawai Honorer Pustikomhub

\subsection{User Interface}

Berikut adalah tampilan atau user interface Sistem Rekapituasi Absensi dan Penggajian berbasis web dari program yang diusulkan.

1. Tampilan Login Admin

Gambar 9 menampilkan nama aplikasi dan form login untuk admin.

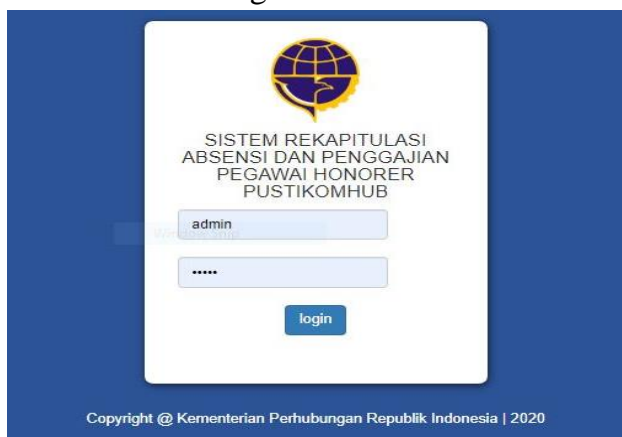

Gambar 9. Tampilan login admin 


\section{Tampilan Halaman Dashboard}

Gambar 10 menampilkan jumlah kehadiran, alpa dan lupa absen terbanyak dan tersedikit yang digunakan untuk pemantauan tingkat kedisiplinan pegawai.

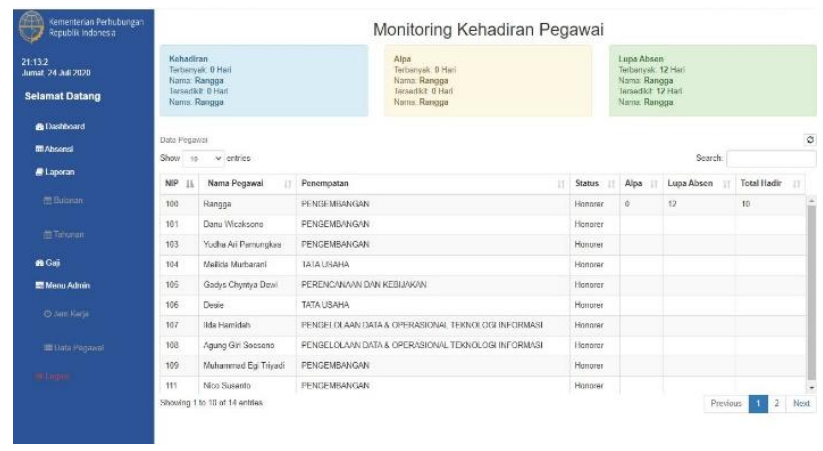

Gambar 10. Tampilan Halaman Dashboard

\section{Tampilan Halaman Absensi}

Gambar 11-12 menampilkan daftar kehadiran per pegawai. Dalam tampilan ini halaman detail absensi pada masing-masing pegawai, admin dapat mengimport data, edit keterangan dan melihat tampilan pdf data absensi pegawai selama setahun
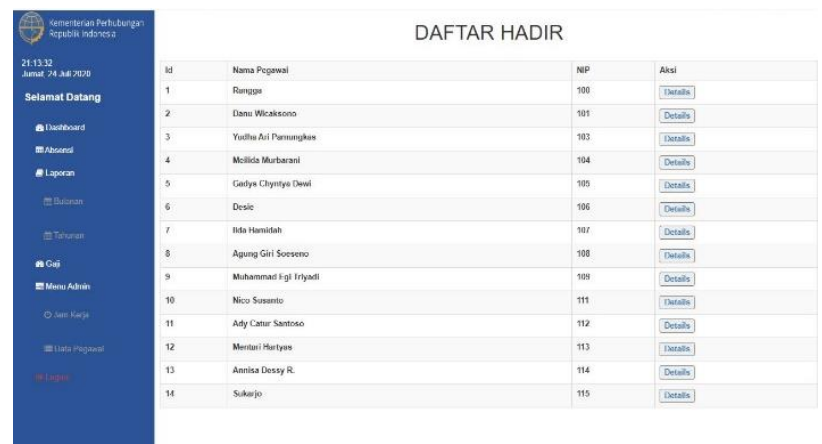

Gambar 11. Tampilan Halaman Absensi
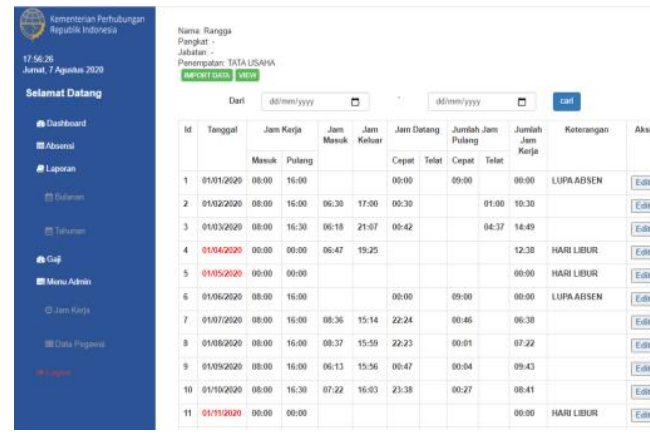

Gambar 12. Tampilan Details

\section{Tampilan Halaman Laporan Absensi Bulanan}

Gambar 13-14 menampilkan laporan absensi bulanan masing - masing pegawai yang dapat diunduh menjadi file pdf.

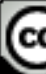

Ciptaan disebarluaskan di bawah Lisensi Creative Commons Atribusi 4.0 Internasional. 


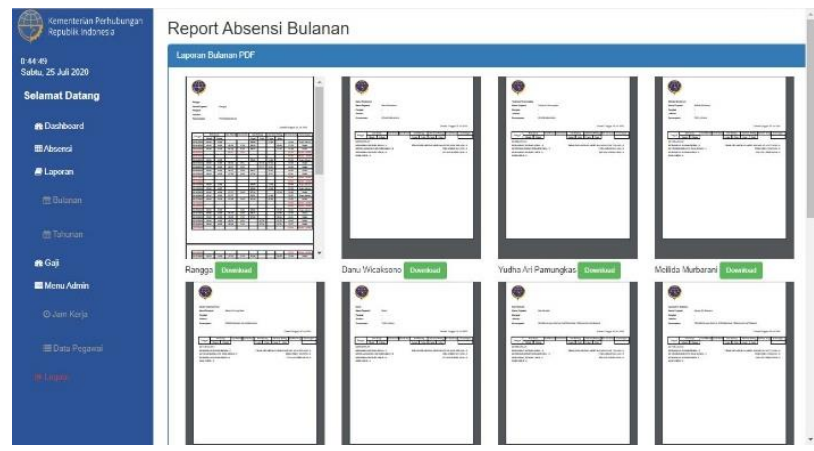

Gambar 13. Tampilan Halaman Laporan Absensi Bulanan

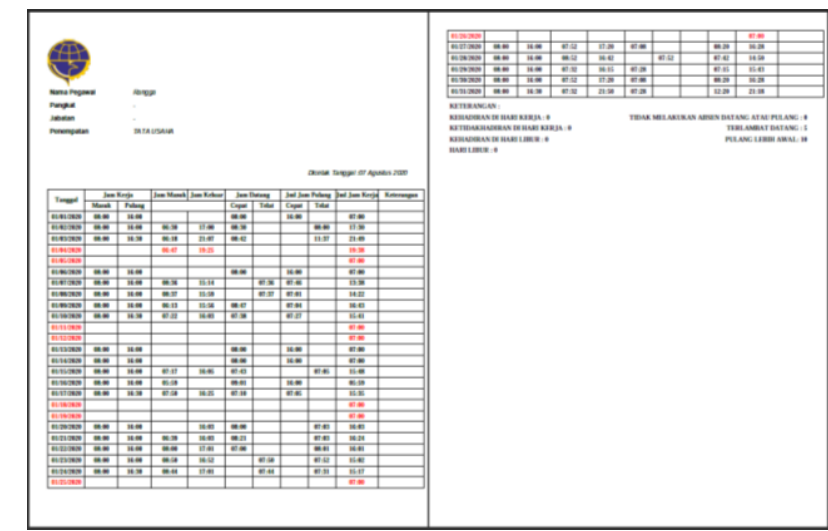

Gambar 14. Tampilan pdf Laporan Absensi Pegawai Bulanan

\section{Tampilan Halaman Laporan Absensi Tahunan}

Gambar 15 menampilkan report absensi tahunan yang berisikan rekapitulasi izin, sakit, alpa, lupa absen, pulang cepat dan terlambat datang juga jumlah ketidakhadiran selama satu tahun.

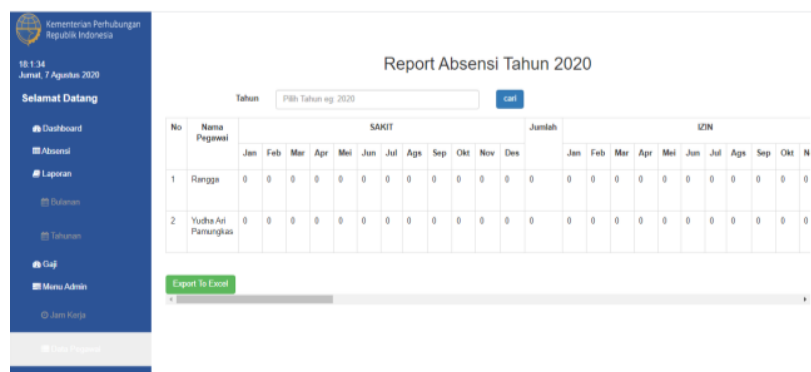

Gambar 15. Tampilan Laporan Absensi Tahunan

\section{Tampilan Halaman Rekapitulasi Gaji}

Gambar 16 menunjukan rekapitulasi penerimaan gaji pegawai selama satu tahun termasuk potongan gaji pegawai. 


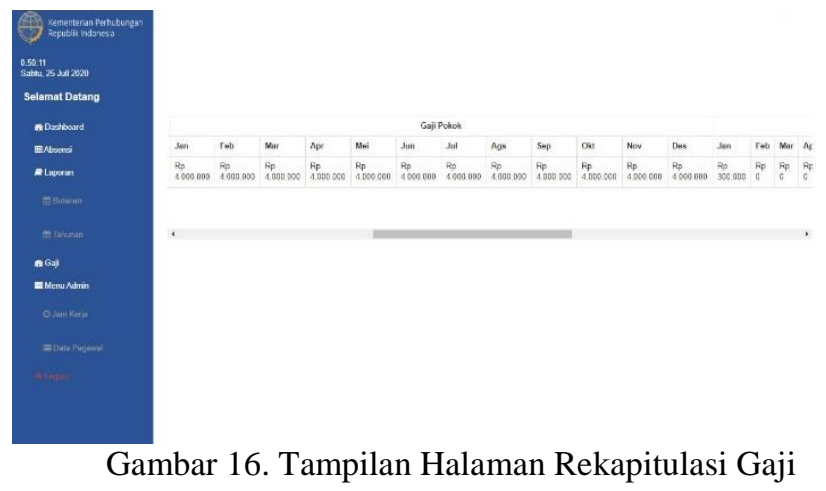

7. Tampilan Menu Admin atau Settings ( Jam Kerja )

Gambar 17 menunjukan admin dapat melakukan perubahan pada jam datang dan jam pulang kerja pegawai.

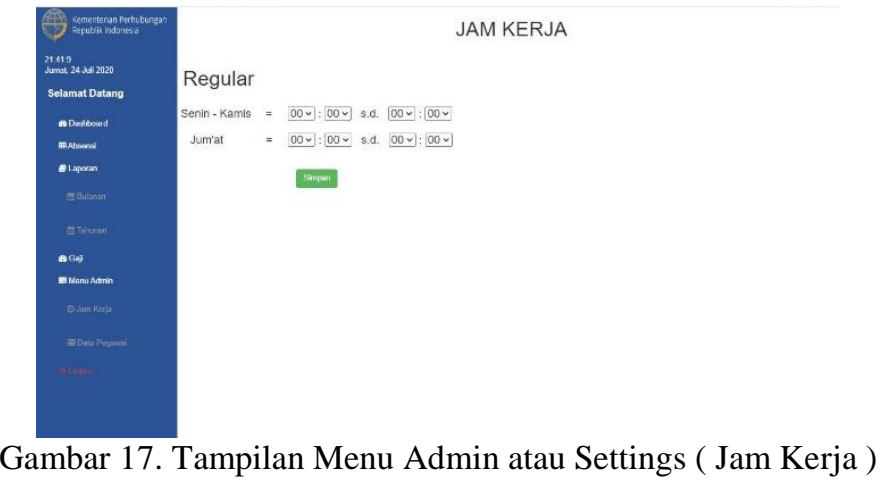

\section{Tampilan Menu Admin atau Settings ( Data Pegawai )}

Gambar 18 menampilkan data pegawai, pada halaman ini admin dapat menambahkan, menghapus dan mengedit data pegawai.

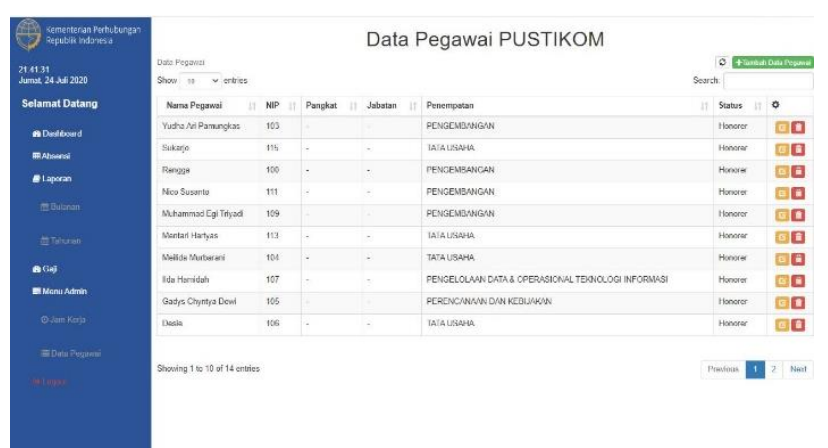

Gambar 18. Tampilan Menu Admin atau Settings ( Data Pegawai ) 
Journal of Information System, Applied, Management, Accounting and Research. http://journal.stmikjayakarta.ac.id/index.php/jisamar, jisamar@stmikjayakarta.ac.id, jisamar2017@gmail.com e-ISSN: 2598-8719 (Online), p-ISSN: 2598-800 ( Printed), Vol. 5, No.1 Februari 2021

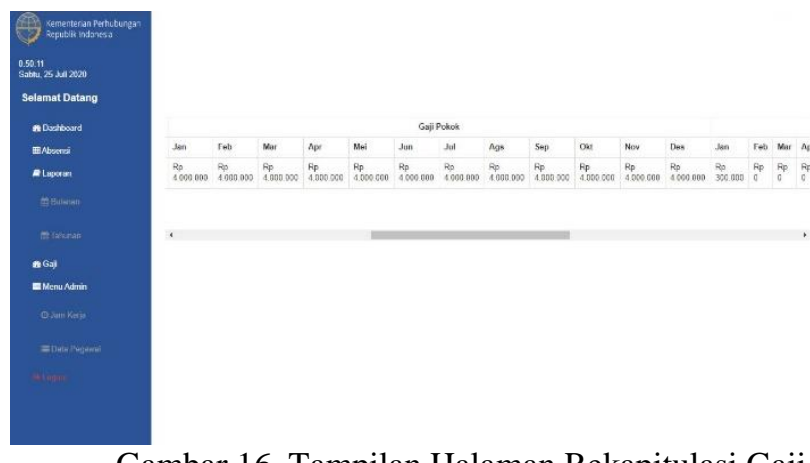

Gambar 16. Tampilan Halaman Rekapitulasi Gaji

\subsection{Code Generation}

Berikut adalah tampilan coding Sistem Rekapitulasi Absensi dan Penggajian Berbasis web dari program yang diusulkan.

\section{Dashboard}

Gambar 19-20 menggambarkan coding untuk menampilkan halaman Dashboard.

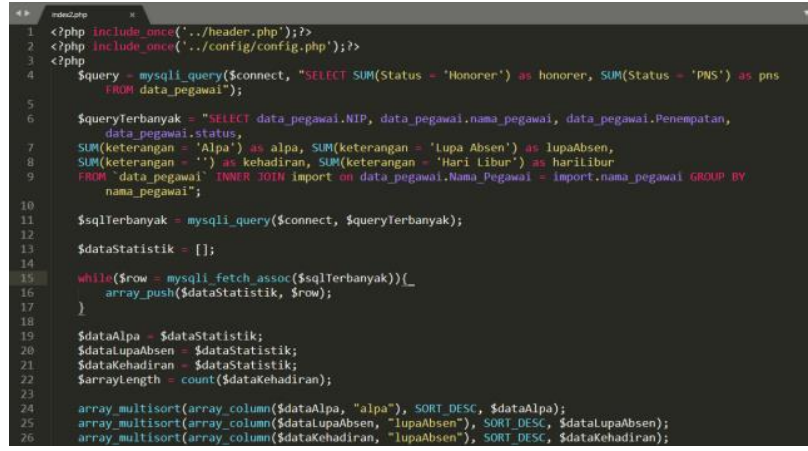

Gambar 19. Memanggil Quary

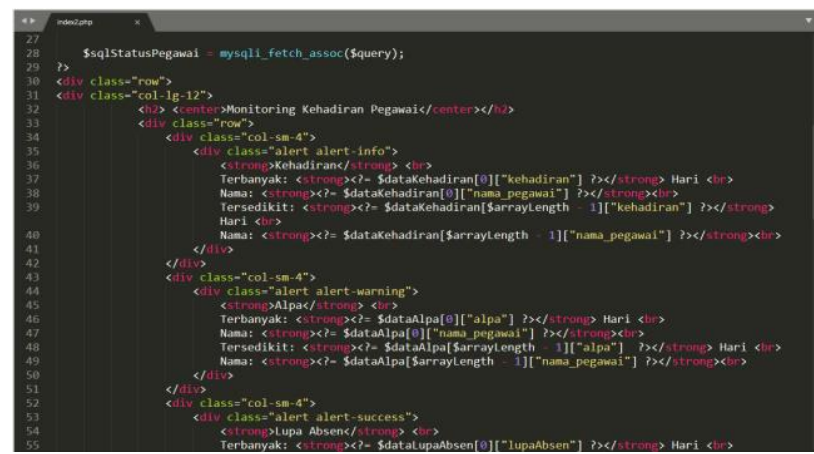

Gambar 20. Membuat Tabel Monitoring Kehadiran Pegawai

\section{Detail Absensi}

Gambar 21-22 menggambarkan coding untuk menampilkan halaman Detail Absensi.

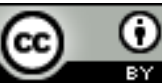

Ciptaan disebarluaskan di bawah Lisensi Creative Commons Atribusi 4.0 Internasional. 
Journal of Information System, Applied, Management, Accounting and Research. http://journal.stmikjayakarta.ac.id/index.php/jisamar, jisamar@stmikjayakarta.ac.id, jisamar2017@gmail.com e-ISSN: 2598-8719 (Online), p-ISSN: 2598-800 ( Printed) , Vol. 5, No.1 Februari 2021

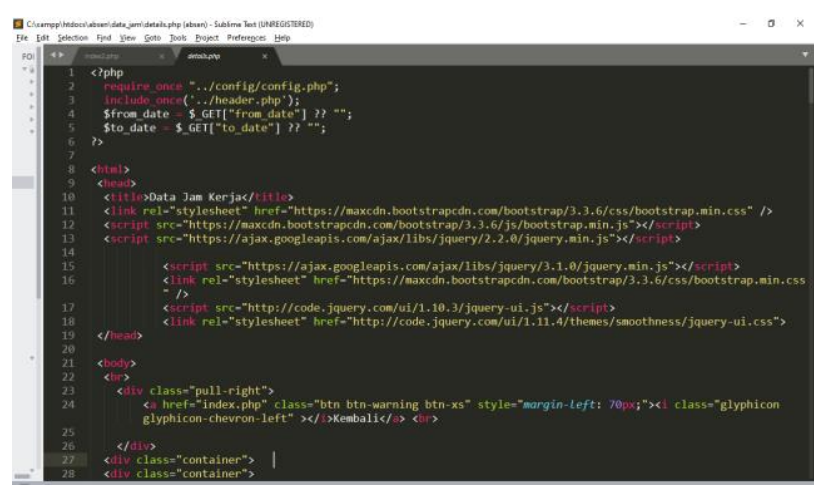

Gambar 21. Membuat Halaman Detail Absensi

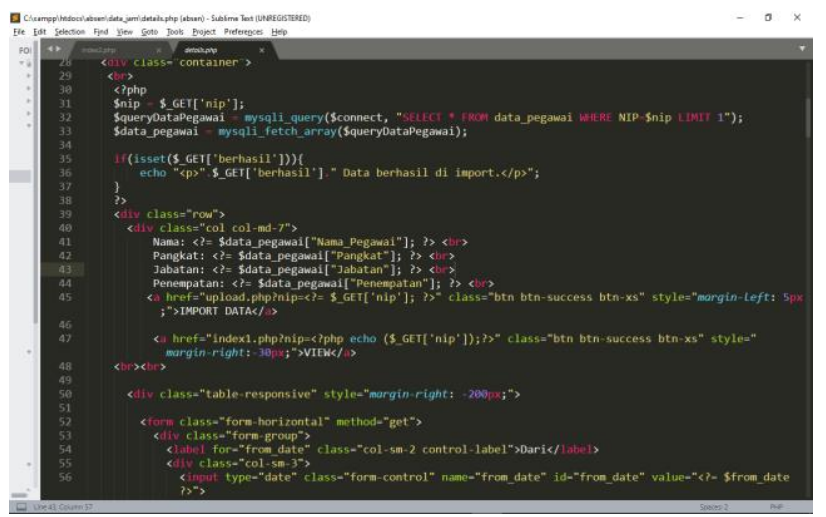

Gambar 22. Membuat label Nama, Pangkat, Jabatan dan Penempatan

\section{Laporan Absen Bulanan}

Gambar 23 menggambarkan coding untuk menampilkan laporan absen bulanan pegawai

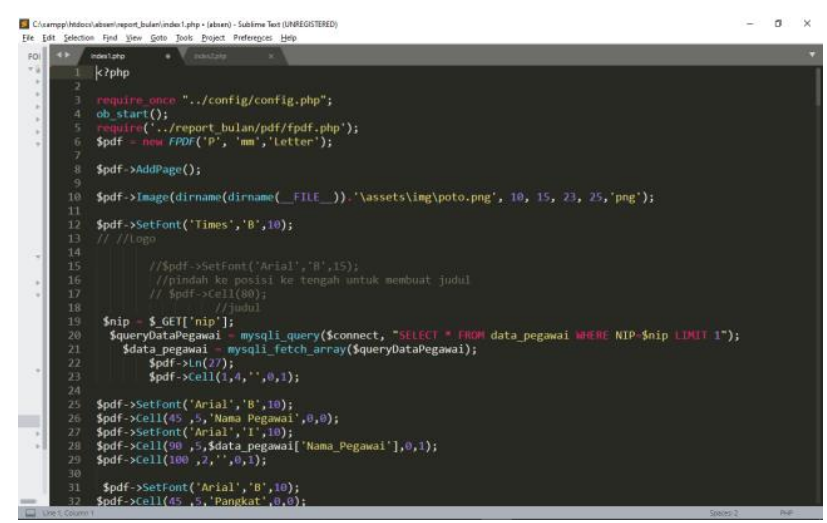

Gambar 23. Membuat Tabel Pdf pada Halaman Laporan Absen Bulanan

\section{Laporan Absen Tahunan}

Gambar 24 - 26 menggambarkan coding untuk menampilkan laporan absen tahunan pegawai.

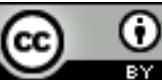

Ciptaan disebarluaskan di bawah Lisensi Creative Commons Atribusi 4.0 Internasional. 
Journal of Information System, Applied, Management, Accounting and Research. http://journal.stmikjayakarta.ac.id/index.php/jisamar , jisamar@stmikjayakarta.ac.id, jisamar2017@gmail.com e-ISSN: 2598-8719 (Online), p-ISSN: 2598-800 ( Printed), Vol. 5, No.1 Februari 2021

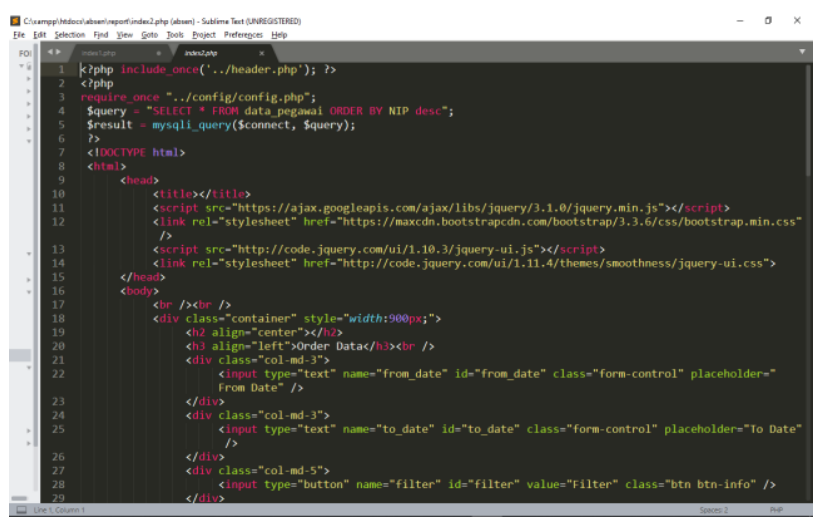

Gambar 24. Membuat Tabel pada Halaman Laporan Absen Tahunan

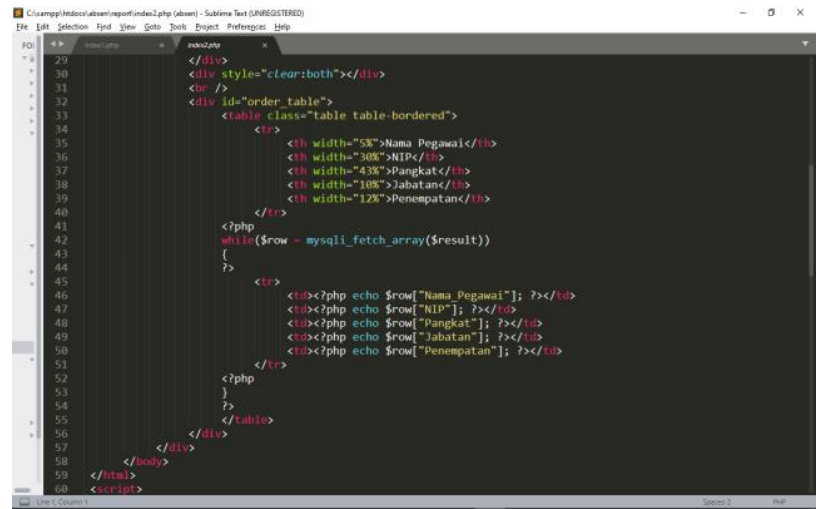

Gambar 25. Membuat Label Nama Pegawai, NIP, Pangkat, Jabatan dan Penempatan pada Halaman Laporan Absen Tahunan

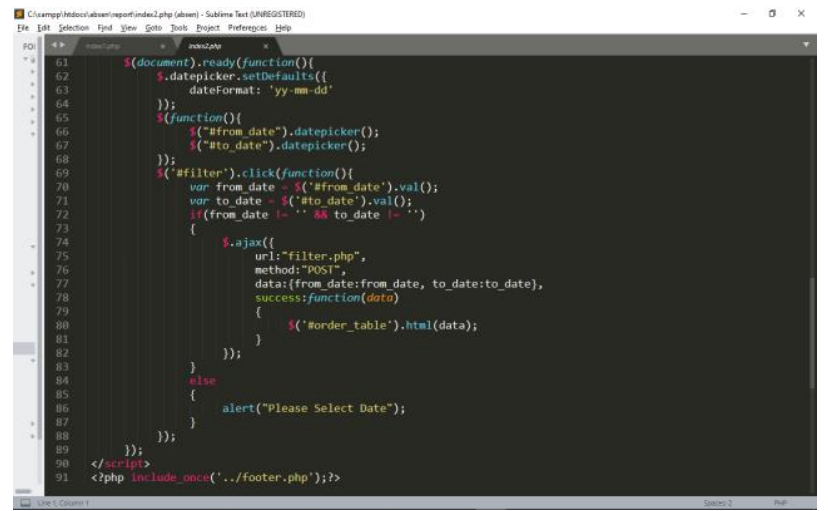

Gambar 26. Menambahkan fungsi pencarian pada Halaman Laporan Absen Tahunan

\section{Laporan Gaji Tahunan}

Gambar 27 menggambarkan coding untuk menampilkan laporan gaji tahunan pegawai. 
Journal of Information System, Applied, Management, Accounting and Research. http://journal.stmikjayakarta.ac.id/index.php/jisamar , jisamar@stmikjayakarta.ac.id , jisamar2017@gmail.com e-ISSN: 2598-8719 (Online), p-ISSN: 2598-800 ( Printed), Vol. 5, No.1 Februari 2021

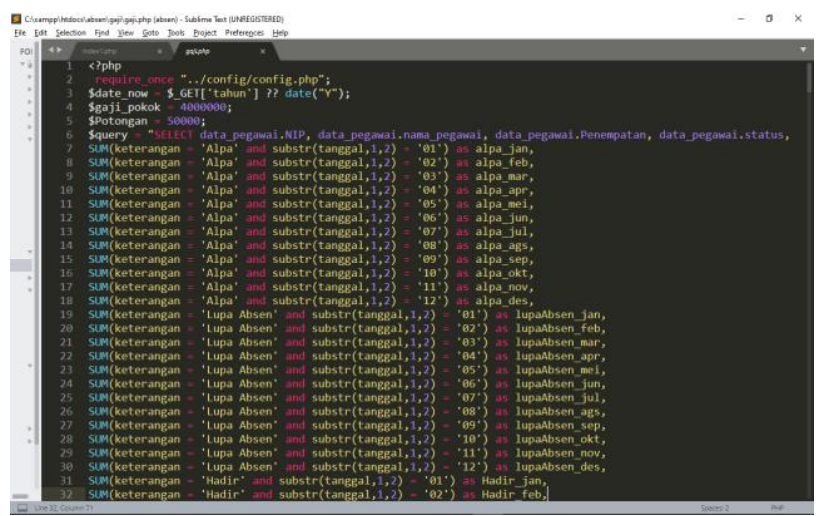

Gambar 27. Menambahkan fungsi pada Halaman Laporan Gaji Tahunan Pegawai

\section{Data Pegawai}

Gambar 28 menggambarkan coding untuk menampilkan Data Pegawai.

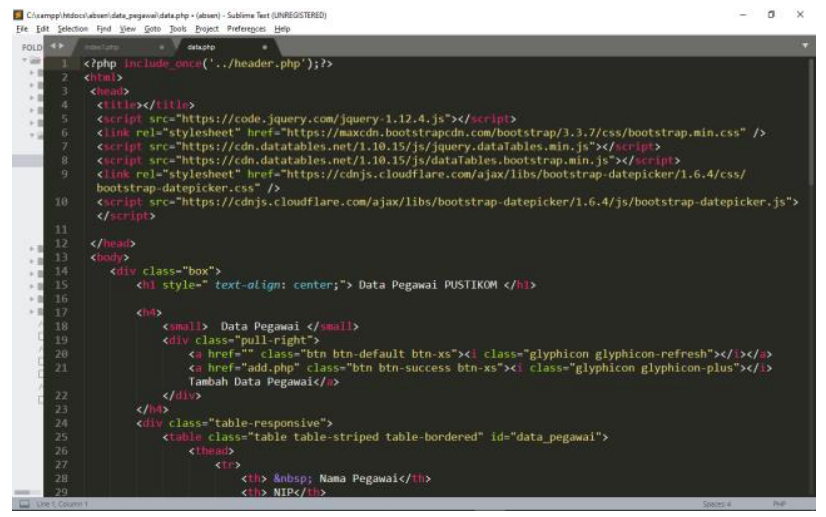

Gambar 28. Membuat Form Data Pegawai

\subsection{Testing}

Testing ini bertujuan untuk mencari kesalahan atau error pada Sistem Rekapitulasi dan Penggajian Pegawai Honorer Pustikomhub agar dapat diperbaiki sebelum aplikasi ini dipergunakan.

\section{Pengujian Form Login}

Hasil pengujian form login Sistem Rekapitulasi dan Penggajian Pegawai Honorer Pustikomhub ditampilkan pada Tabel 6.

Tabel 6.

Hasil Black Box Testing Form Login

\begin{tabular}{|c|c|c|c|c|}
\hline Skenario pengujian & Test Case & Hasil yang diharapkan & $\begin{array}{c}\text { Hasil } \\
\text { pengujian }\end{array}$ & Kesimpulan \\
\hline $\begin{array}{c}\text { Username dan password } \\
\text { tidak diisi kemudian klik } \\
\text { tombol Login }\end{array}$ & $\begin{array}{c}\text { Username: } \\
\text { (kosong) } \\
\text { Password: } \\
\text { (kosong) }\end{array}$ & $\begin{array}{c}\text { Sistem menolak dan } \\
\text { menampilkan "Please } \\
\text { fill out this field" }\end{array}$ & $\begin{array}{c}\text { Sesuai } \\
\text { harapan }\end{array}$ & Valid \\
\hline
\end{tabular}




\begin{tabular}{|c|c|c|c|c|}
\hline $\begin{array}{c}\text { Username dan password } \\
\text { diisi dengan salah kemudian } \\
\text { klik tombol Login }\end{array}$ & $\begin{array}{l}\text { Username: } \\
\text { (user) } \\
\text { Password: } \\
\text { (user) }\end{array}$ & $\begin{array}{c}\text { Sistem menolak dan } \\
\text { menampilkan "LOGIN } \\
\text { GAGAL! } \\
\text { Username/Password } \\
\text { Salah" } \\
\end{array}$ & $\begin{array}{c}\text { Sesuai } \\
\text { harapan }\end{array}$ & Valid \\
\hline $\begin{array}{c}\text { Username dan password } \\
\text { diisi dengan benar kemudian } \\
\text { klik tombol Login }\end{array}$ & $\begin{array}{l}\text { Username: } \\
\text { (admin) } \\
\text { Password: } \\
\text { (admin) }\end{array}$ & $\begin{array}{c}\text { Sistem menerima akses } \\
\text { dan menampilkan } \\
\text { halaman dashboard }\end{array}$ & $\begin{array}{c}\text { Sesuai } \\
\text { harapan }\end{array}$ & Valid \\
\hline
\end{tabular}

\section{Pengujian Form Tambah Data Pegawai}

Hasil pengujian form tambah data pegawai Sistem Rekapitulasi dan Penggajian Pegawai Honorer Pustikomhub ditampilkan pada Tabel 7.

Tabel 7.

Hasil Black Box Testing Form Tambah Data Pegawai

\begin{tabular}{|c|c|c|c|c|}
\hline Skenario pengujian & Test Case & $\begin{array}{l}\text { Hasil yang } \\
\text { diharapkan }\end{array}$ & $\begin{array}{c}\text { Hasil } \\
\text { pengujian }\end{array}$ & Kesimpulan \\
\hline $\begin{array}{l}\text { Nama Pegawai, NIP, } \\
\text { Pangkat, Jabatan, } \\
\text { Penempatan, Status } \\
\text { Klik Simpan }\end{array}$ & $\begin{array}{c}\text { Nama } \\
\text { Pegawai : } \\
\text { (kosong) } \\
\text { NIP : (kosong) } \\
\text { Pangkat : } \\
\text { (kosong) } \\
\text { Jabatan : } \\
\text { (kosong) } \\
\text { Penempatan : } \\
\text { (kosong) } \\
\text { Status : } \\
\text { (kosong) }\end{array}$ & $\begin{array}{l}\text { Sistem menolak dan } \\
\text { menampilkan "Please } \\
\text { fill out this field" }\end{array}$ & $\begin{array}{c}\text { Sesuai } \\
\text { harapan }\end{array}$ & Valid \\
\hline $\begin{array}{c}\text { Nama Pegawai, NIP, Pangkat, } \\
\text { Jabatan, Penempatan, Status } \\
\text { Klik Simpan }\end{array}$ & $\begin{array}{c}\text { Nama Pegawai : } \\
\text { (Agus } \\
\text { Purwanto) } \\
\text { NIP : (116) } \\
\text { Pangkat : (-) } \\
\text { Jabatan : (-) } \\
\text { Penempatan : } \\
\text { (PERENCANA } \\
\text { AN DAN } \\
\text { KEBIJAKAN) } \\
\text { Status : } \\
\text { (Honorer) }\end{array}$ & $\begin{array}{c}\text { Sistem menerima } \\
\text { inputan data dan } \\
\text { menampilkan kembali } \\
\text { halaman Data Pegawai }\end{array}$ & Sesuai harapan & Valid \\
\hline
\end{tabular}

\section{Pengujian Form Data Absensi Pegawai}

Hasil pengujian form tambah data pegawai Sistem Rekapitulasi dan Penggajian Pegawai Honorer Pustikomhub ditampilkan pada Tabel 8.

Tabel 8.

Hasil Black Box Testing Form Data Pegawai

\begin{tabular}{|l|l|c|c|c|c|}
\hline & Skenario pengujian & Test Case & Hasil yang diharapkan & $\begin{array}{c}\text { Hasil } \\
\text { pengujian }\end{array}$ & Kesimpulan \\
\hline
\end{tabular}




\begin{tabular}{|c|c|c|c|c|c|}
\hline 1 & Melihat detail absensi & Detail : (dipilih) & Tampil Detail data absensi & $\begin{array}{c}\text { Sesuai } \\
\text { harapan }\end{array}$ & Valid \\
\hline 2 & $\begin{array}{l}\text { Import data lalu tampil } \\
\text { form import absen } \\
\text { pegawai lalu pilih data } \\
\text { kemudian klik import }\end{array}$ & $\begin{array}{l}\text { Import Data : } \\
\text { (dipilih) }\end{array}$ & $\begin{array}{c}\text { Sistem menampilkan pesan } \\
\text { data "data berhasil } \\
\text { diimport" }\end{array}$ & $\begin{array}{l}\text { Sesuai } \\
\text { harapan }\end{array}$ & Valid \\
\hline 3 & $\begin{array}{l}\text { Mengubah data } \\
\text { keterangan lalu tampil } \\
\text { form edit keterangan } \\
\text { kemudian klik simpan }\end{array}$ & Edit : (dipilih) & $\begin{array}{c}\text { Tampil Detail data absensi } \\
\text { dengan data keterangan } \\
\text { yang sudah diedit }\end{array}$ & $\begin{array}{l}\text { Sesuai } \\
\text { harapan }\end{array}$ & Valid \\
\hline 4 & $\begin{array}{l}\text { Melihat data absensi yang } \\
\text { sudah diexport ke file pdf }\end{array}$ & View : (dipilih) & $\begin{array}{l}\text { Tampil data absensi yang } \\
\text { sudah diexport ke file pdf }\end{array}$ & $\begin{array}{c}\text { Sesuai } \\
\text { harapan }\end{array}$ & Valid \\
\hline
\end{tabular}

\subsection{Support}

Support yang dimaksud pada Sistem Rekapitulasi dan Penggajian Pegawai Honorer Pustikomhub adalah Perangkat Keras dan Perangkat Lunak yang digunakan penulis dalam pembuatan aplikasi ini.

\section{Spesifikasi Hardware dan Software}

Spesifikasi hardware dan software yang digunakan penulis dalam pembuatan Sistem Rekapitulasi dan Penggajian Pegawai Honorer Pustikomhub ditampilkan pada Tabel 9 dan Tabel 10.

Tabel 9.

Spesifikasi Hardware (Perangkat Keras)

\begin{tabular}{|l|l|}
\hline \multicolumn{1}{|c|}{ Kebutuhan } & \multicolumn{1}{c|}{ Keterangan } \\
\hline Processor & $\begin{array}{l}\text { Intel }{ }^{\mathrm{C}} \text { Core } \\
2.70 \mathrm{GHz} \text { (7)-2620M CPU C }\end{array}$ \\
\hline RAM & $8 \mathrm{~GB}$ \\
\hline Harddisk & $500 \mathrm{~GB}$ \\
\hline Monitor & Standard 14" \\
\hline Printer & Inject \\
\hline Keyboard/mouse & Standard \\
\hline
\end{tabular}

Tabel 10.

\begin{tabular}{|l|l|}
\multicolumn{2}{c}{ Spesifikasi Software (Perangkat Lunak) } \\
\hline \multicolumn{1}{|c|}{ Kebutuhan } & \multicolumn{1}{c|}{ Keterangan } \\
\hline Sistem Operasi & Windows 10 64-bit \\
\hline Browser & Google Chrome, Microsoft Edge \\
\hline Software & Sublime Text, MySQL, Apache, XAMPP, PHP MyAdmin \\
\hline
\end{tabular}

\section{KESIMPULAN}

Sistem berjalan dengan baik, semua rekapitulasi absen bulanan ataupun tahunan termasuk rekap penggajian sudah tertata rapi didalam sistem dan bisa di cari berdasarkan hari, bulan ataupun tahun.

1. Di dalam sistem ini, kedepannya bisa terintegrasi dengan fingerprint dari Biro Umum agar tidak adanya pengerjaan dua kali saat melakukan rekapitulasi absen.

2. Di dalam sistem ini, bisa ditambahkan cetak slip gaji untuk arsip pegawai.

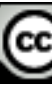




\section{REFERENASI}

[1] D. Purba, "Sistem Informasi Akuntansi Penggajian Dan Pengupahan: Studi Kasus Pada Sebuah Rumah Sakit," J. Manaj., vol. 4, no. 1, pp. 15-22, 2018.

[2] S. Aswati, N. Mulyani, Y. Siagian, and A. Z. Syah, "Peranan Sistem Informasi Dalam Perguruan Tinggi," J. Teknol. dan Sist. Inf., vol. 1, no. 2, pp. 79-86, 2015, [Online]. Available: http://is.its.ac.id/pubs/oajis/index.php/file/download_file/1466.

[3] R. Yanto, "Manajemen Basis Data Menggunakan MySQL," in Manajemen Basis Data Menggunakan MySQL, 1st ed., Yogyakarta: Deepublish, 2018, p. 243 halaman.

[4] W. Komputer, "Shortcourse series Adobe Photoshop CS 6," in Shortcourse series Adobe Photoshop CS 6, Shortcours., WESTRININGSIH, Ed. Yogyakarta: PENERBIT ANDI, 2012, p. 242.

[5] Pengembangan Sistem Penggajian pada Kantor Pelayanan Kekayaan Negara dan Lelang ( KPKLN ) Kota Metro,” J. Komputasi, vol. 1, no. 2, pp. 20-29, 2014.

[6] Abdullah, "Rancang Bangun Sistem Informasi," Romney dan Steinbart, no. tahun 2016, pp. 7-25, 2015.

[7] H. K. Siradjuddin, "Sistem Informasi Pariwisata Sebagai Media Promosi Pada Dinas Kebudayaan Dan Pariwisata Kota Tidore Kepulauan,” IJIS - Indones. J. Inf. Syst., vol. 3, no. 2, pp. 46-55, 2018, doi: 10.36549/ijis.v3i2.43.

[8] H. Kusumahati, "SI1311476759 - widuri." [Online]. Available: http://widuri.raharja.info/index.php/SI1311476759\#Konsep_Dasar_UML_.28Unified_Mod eling_Language. 29.

[9] H. Santoso and A. W. Yulianto, "Analisa Dan Perancangan Sistem Absensi Siswa Berbasis Web Dan Sms Gateway," J. Matrik, vol. 16, no. 2, p. 65, 2017, doi: 10.30812/matrik.v16i2.11.

[10] A. Samad, S. H. Hadad, P. Studi, M. Informatika, P. Studi, and T. Komputer, "Sistem Informasi Kependudukan Pada Kantor Lurah Sangaji Berbasis Web,” vol. 2, no. 2, pp. 60-67, 2019.

[11] Agnitia L. Mita, T. Muhamad, and A. Surtika, "Sistem Informasi Pengolahan Data Administrasi Kependudukan Pada Kantor Desa Pucung Karawang," J. Interkom Vol. 13 No. 3, vol. 13, no. 3, pp. 14-21, 2018.

[12] J. Akuntansi, “3 1,2,3,” vol. 14, no. 1, pp. 148-153, 2019.

[13] S. Sumiyati, Y. Nawangsasi, and I. Gustirani, "Database Paket Kontraktual Berbasis Web," J. Pendidik. Akunt. Keuang., vol. 6, no. 2, p. 67, 2018, doi: 10.17509/jpak.v6i2.16246.

[14] D. Pradiatiningtyas and Suparwanto, "E-Learning Sebagai Media Pembelajaran Berbasis Web Pada Smk N 4 Purworejo," Indones. Netw., vol. 7, no. 2, pp. 1-8, 2017, [Online]. Available: https://ijns.org/journal/index.php/ijns/article/download/1499/1460.

[15] F. Ayu and N. Permatasari, "Perancangan Sistem Informasi Pengolahan Data Praktek Kerja Lapangan (Pkl) Pada Devisi Humas Pt. Pegadaian,” Intra-Tech, vol. 2, no. 2, pp. 
Journal of Information System, Applied, Management, Accounting and Research. http://journal.stmikjayakarta.ac.id/index.php/jisamar, jisamar@stmikjayakarta.ac.id , jisamar2017@gmail.com e-ISSN: 2598-8719 (Online), p-ISSN: 2598-800 ( Printed), Vol. 5, No.1 Februari 2021

12-26, 2018.

[16] N. Hidayatun, "Problem Solving Sistem Penggajian Karyawan Dalam Manajemen Operasional Komputer Menggunakan Pendekatan Sistem," Ijcit, vol. 1, no. 2, pp. 1-9, 2016, [Online].

[17] Available: https://ejournal.bsi.ac.id/ejurnal/index.php/ijcit/article/view/1320.

[18] M. Muhyar and K. Siahaan, "Informasi Penggajian Karyawan Pada Pt Tridaya Dimensi Indonesia Jambi," vol. 4, no. 4, pp. 410-422, 2019.

[19] N. Anggraini and A. R. Octivaningsih, "Penerapan Sistem Pengendalian Internal Atas Sistem Prosedur Pembayaran Gaji Berbasis Komputerisasi Pada Sma Mulia Plus,” J. Manaj. Indones., vol. 16, no. 2, p. 126, 2017, doi: 10.25124/jmi.v16i2.318.

[20] Struktur Organisasi Pusat Teknologi Informatika dan Komunikasi Perhubungan Sekretariat Jenderal Kementerian Perhubungan.

[21] http://jdih.dephub.go.id/assets/uudocs/permen/2018/PM_122_TAHUN_2018.pdf

Ciptaan disebarluaskan di bawah Lisensi Creative Commons Atribusi 4.0 Internasional. 